\title{
Encephalopathy with Isolated Reversible Splenial Lesion of the Corpus Callosum
}

\author{
Masamitsu YAGUCHI, Hisa YAGUCHI, Tetsuro ITOH* and Koichi OKAMOTO**
}

\begin{abstract}
We report a 51-year-old Japanese man with chronic alcoholism who complained of mental confusion following respiratory and intestinal infections. The splenium of the corpus callosum showed hyperintensity on both diffusion-weighted MR images and fluid-attenuated inversion recovery images and hypointensity on T1-weighted images. These findings were resolved on MR images obtained 3 days later. He showed complete neurological recovery within 2 months. We suspected that he had mild encephalopathy with a reversible splenial lesion after systemic viral or bacterial infection.
\end{abstract}

(Internal Medicine 44: 1291-1294, 2005)

Key words: encephalopathy, splenium of the corpus callosum, infection, MRI, diffusion-weighted image

\section{Introduction}

The prevalence of acquired lesions of the corpus callosum was estimated to be about 3\% in a MR study of 450 patients and the differential diagnosis of corpus callosum abnormalities is considered to be difficult (1). Splenial lesions in the corpus callosum include Marchiafava-Bignami disease, ischemia, diffuse axonal injury, multiple sclerosis, hydrocephalus, tumors, epilepsy, antiepileptic drugs, hypoglycemia, cerebral malaria and encephalitis/encephalopathy (1-7).

We report a man with chronic alcoholism, who complained of acute confusion following a one-day illness with cough and diarrhea, and showed an isolated reversible splenial lesion of the corpus callosum on MR images.

\section{Case Report}

A 51-year-old Japanese man was admitted to our hospital because of high fever $\left(39.8^{\circ} \mathrm{C}\right)$ and mental confusion following a one-day illness with cough and diarrhea. He had a long history of alcoholism, drinking over $400 \mathrm{ml}$ of rough distilled spirits (proof 20\%) every day. He was confused and disoriented, but there were no signs of meningeal irritation. Oculomotor and cranial nerve functions were normal. Neither ataxia, paresis nor asterixis were observed. Deep tendon reflexes on the extremities were normal, and plantar responses were flexor. Chest $\mathrm{X}$ ray disclosed pneumonia in the right lower lung field. Laboratory tests showed elevations of CK, AST, ALT, BUN, CRE and CRP (Table 1). Serum vitamins were not measured. Mycoplasma pneumoniae antibody and Chlamydia psittaci antibody were negative. Cerebrospinal fluid (CSF) studies were normal. Rapid antigen detection assay from a nasopharyngeal swab did not demonstrate influenza. There were no pathogenic organisms isolated from blood or sputum. Cultures of the stool were not performed. Electroencephalography (EEG) showed slow basic activities with no paroxysmal discharges. Abdominal ultrasonography was normal. MR images on admission (Fig. 1A-C) demonstrated an isolated small lesion in the splenium of the corpus callosum that was markedly hyperintense on diffusionweighted images (DWI), hyperintense on fluid-attenuated inversion recovery (FLAIR) images and slight hypointense on T1-weighted images (T1WI). A few small areas showing high signals were seen in the cerebral white matter. Steady clinical recovery was noted following treatment with intravenous administration of vitamin B complex and antibiotics. On follow-up MR studies (Fig. 1D-F) obtained 3 days after the initial study, resolution of the abnormality without contrast enhancement was noted. Neuropsychological examinations 3 weeks after admission demonstrated mild impairment of memory and cognitive functions but there was no sign of callosal disconnection. His score on the mini-mental state

\footnotetext{
From the Department of Neurology, *the Department of Internal Medicine, Shinoda General Hospital, Yamagata, and **the Department of Neurology, Gunma University Graduate School of Medicine, Maebashi

Received for publication May 24, 2005; Accepted for publication August 25, 2005

Reprint requests should be addressed to Dr. Masamitsu Yaguchi, the Department of Neurology, Shinoda General Hospital, 2-68 Sakura-machi, Yamagata 990-0045
} 
Table 1.

\begin{tabular}{|c|c|c|c|}
\hline Blood Cell Count & & Glucose & $176 \mathrm{mg} / \mathrm{dl}(70-110)$ \\
\hline WBC & $8,600 / \mathrm{mm}^{3}(4,100-9,500)$ & $\mathrm{NH}_{3}$ & $\overline{63 \mu \mathrm{g} / \mathrm{dl}(12-66)}$ \\
\hline $\mathrm{RBC}$ & $455 \times 10^{4} / \mathrm{mm}^{3}(420-560)$ & CRP & $47.4 \mathrm{mg} / \mathrm{dl}(<0.47)$ \\
\hline $\mathrm{Hb}$ & $15.3 \mathrm{~g} / \mathrm{dl}(13-17)$ & TSH & $\overline{1.12 \mu \mathrm{IU} / \mathrm{ml}}(0.05-5.00)$ \\
\hline Het & $44.3 \%(40-51)$ & $\mathrm{FT}_{3}$ & $2.96 \mathrm{pg} / \mathrm{ml}(2.30-4.30)$ \\
\hline Plt & $9.1 \times 10^{4} / \mathrm{mm}^{3}(15.4-33.0)$ & $\mathrm{FT}_{4}$ & $1.42 \mathrm{ng} / \mathrm{dl}(0.90-1.70)$ \\
\hline Blood Chemistry & & Urinalysis & \\
\hline T-Bil & $0.8 \mathrm{mg} / \mathrm{dl}(0.2-1.2)$ & protein & $(2+)$ \\
\hline $\mathrm{TP}$ & $6.4 \mathrm{~g} / \mathrm{dl}(6.5-8.3)$ & occult blood & $(3+)$ \\
\hline AST & $\overline{278 \mathrm{IU} / l}(8-38)$ & glucose & $(-)$ \\
\hline ALT & $\overline{129 \mathrm{IU} / l}(4-44)$ & ketone & $(-)$ \\
\hline ALP & $170 \mathrm{IU} / \mathrm{l}(104-338)$ & Blood gas analysis & \\
\hline$\gamma$-GTP & $40 \mathrm{IU} / \mathrm{l}(16-73)$ & $\mathrm{pH}$ & $\underline{7.51}(7.35-7.45)$ \\
\hline $\mathrm{CHE}$ & $208 \mathrm{IU} / \mathrm{l}(203-460)$ & $\mathrm{PaCO}_{2}$ & $\overline{30.1} \mathrm{mmHg}(35-45)$ \\
\hline $\mathrm{CK}$ & $\underline{5,990 \mathrm{IU} / l}(56-244)$ & $\mathrm{PaO}_{2}$ & $60.0 \mathrm{mmHg}(80-90)$ \\
\hline T-Cho & $\overline{171 \mathrm{mg} / \mathrm{dl}}(120-220)$ & $\mathrm{HCO}_{3}^{-}$ & $23.7 \mathrm{mmol} / \mathrm{l}(22-26)$ \\
\hline BUN & $48.5 \mathrm{mg} / \mathrm{dl}(8.0-20.0)$ & Base Excess & $0.9 \mathrm{mmol} / \mathrm{l}(0 \pm 2)$ \\
\hline CRE & $2.3 \mathrm{mg} / \mathrm{dl}(0.6-1.1)$ & CSF study & \\
\hline $\mathrm{Na}$ & $\overline{134 \mathrm{mEq} / \mathrm{l}}(135-150)$ & cell count & $3 / 3 \mathrm{~mm}^{3}$ \\
\hline $\mathrm{K}$ & $2.6 \mathrm{mEq} / \mathrm{l}(3.5-5.0)$ & protein & $26 \mathrm{mg} / \mathrm{dl}$ \\
\hline $\mathrm{Cl}$ & $99 \mathrm{mEq} / \mathrm{l}(98-110)$ & glucose & $63 \mathrm{mg} / \mathrm{dl}$ \\
\hline $\mathrm{Ca}$ & $0.97 \mathrm{mmol} / \mathrm{l}(8.5-10.5)$ & $\mathrm{IgG}$ & $2.0 \mathrm{mg} / \mathrm{dl}$ \\
\hline
\end{tabular}

(MMS) was 23/30 points at that time. MMS on day 53 after admission showed a full score.

\section{Discussion}

We report a Japanese man with encephalopathy demonstrating an isolated reversible splenial lesion of the corpus callosum on MR images. The splenial lesion resolved rapidly within a few days, and the complete neurological recovery was obtained within 2 months. A history of long-term chronic alcoholism suggested that he had MarchiafavaBignami disease; however, we suspected another disorder due to the existence of systemic infection preceding central nervous system manifestations.

Recently, Tada et al reported 15 patients with clinically mild encephalitis/encephalopathy with reversible lesions in the splenuim of the corpus callosum on MR images (7). They were relatively young (12 patients were below 20 years old), and fever and/or diarrhea preceded manifestations of the central nervous system including impairments of consciousness, seizures and vertigo. In their report, CSF studies demonstrated normal cell counts or pleocytosis with normal glucose and protein levels. EEG showed slow basic activities. The splenial lesions were hyperintense on T2WI and DWI, and isointense to slightly hypointense on T1WI. There was no enhancement of the lesion after gadolinium administration. Resolution of splenial abnormalities was usually noted within one week on follow-up MR studies, and a complete recovery was obtained within one month. The associated pathogens were varied, including O-157 Escherichia coli (8), measles virus (9), rotavirus (10), Salmonella enteritidis (11), influenza virus $(7,12)$, Legionella pneumophila (13), adenovirus, mumps virus, varicella-zoster virus and an unknown pathogen, however the pathogen was not clarified in 10 of 15 patients (7). It is unknown why the splenium is involved as an isolated site. The pathogenesis is speculated to involve pathogens or antibodies induced by them that directly damage axons or the myelin sheath in the splenium of the corpus callosum $(7,8,10)$, and the participation of elevated inflammatory cytokines such as interleukin-6 is also postulated in the pathogenesis $(7,12)$. However, these hypotheses remain controversial. Except for the history of longterm chronic alcoholism, the clinical and radiological course of the present case is compatible with that of the syndrome. Although the pathogens causing diarrhea and pneumonia were not clarified, there was a possibility that the pathogenesis of encephalopathy in our case was similar to that in the syndrome.

Similar reversible and isolated symmetrical lesions in the splenium of the corpus callosum, which are hyperintense on DWI and T2WI and hypointense on T1WI, could be seen in diffuse axonal injury (14), epilepsy or an influence of antiepileptic drugs (4), hypoglycemia (5) and MarchiafavaBignami disease (15). These diseases are usually differentiated from the encephalitis/encephalopathy reported by Tada et al (7) by their clinical courses and laboratory findings. Minor splenial lesions may be asymptomatic, and MR examinations are not performed routinely in the clinical setting. The incidence of the encephalopathy/encephalitis with reversible splenial lesion after systemic infection might be higher than conceived. It is important for clinicians to note that an isolated reversible splenial lesion is observed in a variety of disorders. 

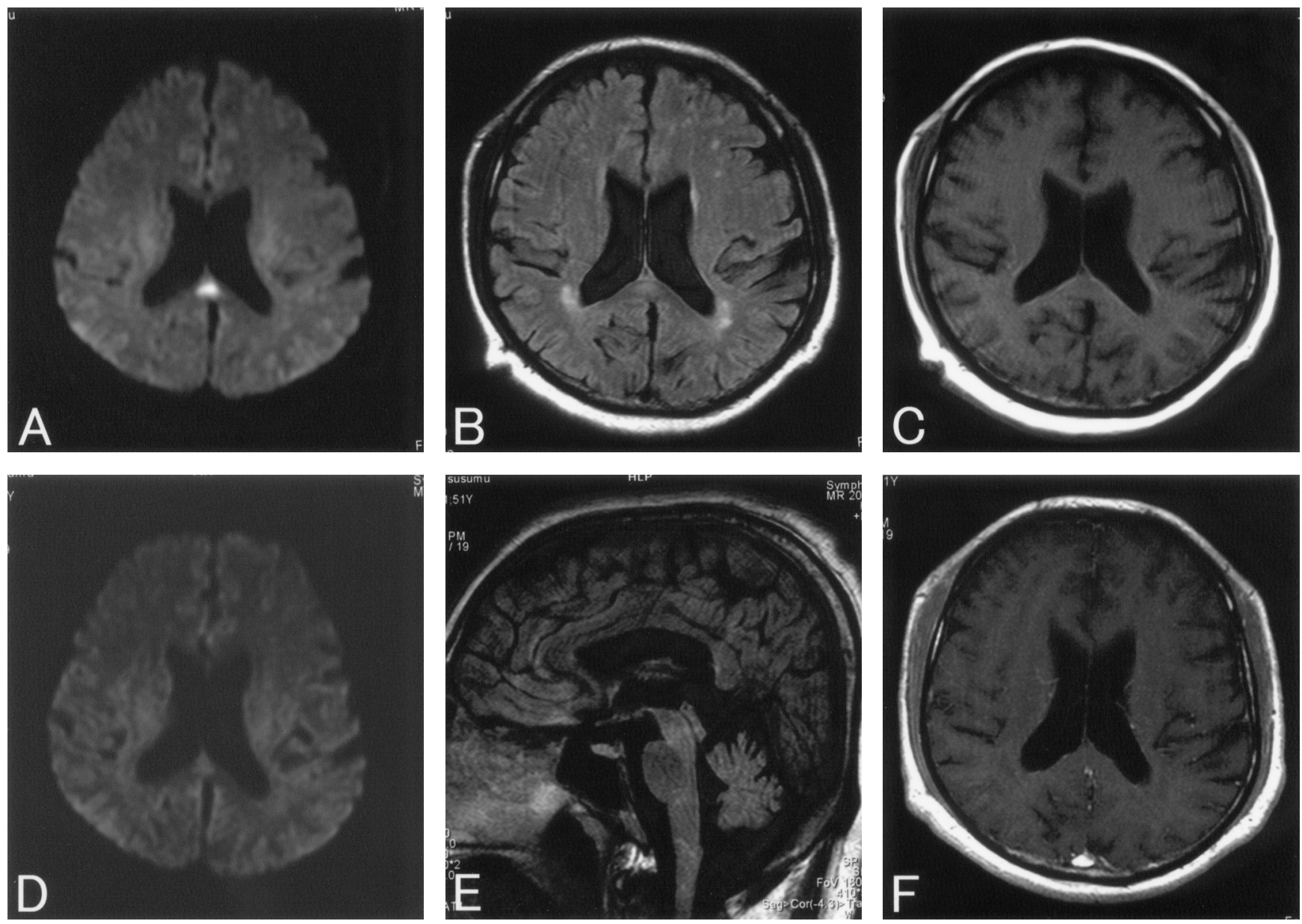

Figure 1. Magnetic resonance (MR) imaging on admission, showing an isolated small lesion in the splenium of the corpus callosum on diffusion-weighted image (DWI) (A), fluid-attenuated inversion recovery (FLAIR) image (B) and T1-weighted image (C). MR imaging on day 5, showing resolutions of the lesion on DWI (D), FLAIR image (E) and enhanced image after gadolinium administration (F).

\section{References}

1) McLeod NA, Williams JP, Machen B, Lum GB. Normal and abnormal morphology of the corpus callosum. Neurology 37: 1240-1242, 1987.

2) Friese SA, Bitzer M, Freudenstein D, Voigt K, Kuker W. Classification of acquired lesions of the corpus callosum with MRI. Neuroradiology 42: 795-802, 2000.

3) Bourekas EC, Varakis K, Bruns D, et al. Lesions of the corpus callosum: MR Imaging and differential considerations in adults and children. AJR Am J Roentgenol 179: 251-257, 2002.

4) Maeda M, Shiroyama T, Tsukahara H, Shimono T, Aoki S, Takeda K. Transient splenial lesion of the corpus callosum associated with antiepileptic drugs: evaluation by diffusion-weighted MR imaging. Eur Radiol 13: 1902-1906, 2003.

5) Takeuchi M, Kawaguchi T, Nakatani M. Reversible increased signal intensities in the splenium on diffusion-weighted imaging caused by transient hypoglycemia. No To Shinkei (in Japanese) 57: 420-421, 2005.

6) Cordoliani YS, Sarrazin JL, Felten D, Caumes E, Leveque C, Fisch A. MR of cerebral malaria. AJNR Am J Neuroradiol 19: 871-874, 1998.

7) Tada H, Takanashi J, Barkovich AJ, et al. Clinically mild encephalitis/ encephalopathy with a reversible splenial lesion. Neurology 63: 1854-
$1858,2004$.

8) Ogura H, Takaoka M, Kishi M, et al. Reversible MR findings of hemolytic uremic syndrome with mild encephalopathy. AJNR Am J Neuroradiol 19: 1144-1145, 1998.

9) Mito Y, Yoshida K, Kikuchi S. Measles encephalitis with peculiar MRI findings. Report of two adult cases. Neurol Med 56: 251-256, 2002 (in Japanese, Abstract in English).

10) Kobata $R$, Tsukahara $H$, Nakai A, et al. Transient MR signal changes in the splenium of the corpus callosum in rotavirus encephalopathy: value of diffusion-weighted imaging. J Comput Assist Tomogr 26: 825-828, 2002.

11) Kobuchi N, Tsukahara H, Kawamura $Y$, et al. Reversible diffusionweighted MR findings of Salmonella enteritidis-associated encephalopathy. Eur Neurol 49: 182-184, 2003.

12) Takanashi J, Barkovich AJ, Yamaguchi K, Kohno Y. Influenzaassociated encephalitis/encephalopathy with a reversible lesion in the splenium of the corpus callosum: a case report and literature review. AJNR Am J Neuroradiol 25: 798-802, 2004.

13) Morgan JC, Cavaliere R, Juel VC. Reversible corpus callosum lesion in Legionnaires' disease. J Neurol Neurosurg Psychiatry 75: 651-654, 2004.

14) Liu AY, Maldjian JA, Bagley LJ, Sinson GP, Grossman RI. Traumatic 


\section{YAGUCHI et al}

brain injury: diffusion-weighted MR imaging findings. AJNR Am J Neuroradiol 20: 1636-1641, 1999.

15) Inagaki T, Saito K. A case of Marchiafava-Bignami disease demon- strated by MR diffusion-weighted image. No To Shinkei 52: 633-637, 2000 (in Japanese, Abstract in English). 